\title{
PENERAPAN ASAS IKTIKAD BAIK PADA PERJANJIAN LISAN (NON KONTRAKTUAL) DALAM TRANSAKSI ANTAR PEDAGANG DENGAN PENYUPLAI BARANG DI PASAR KLEWER
}

\author{
Budi Winarno $^{1}$, Khudzaifah Dimyati², Kelik Wardiono ${ }^{3}$ \\ ${ }^{1}$ Magister Ilmu Hukum, Universitas Muhammadiyah Surakarta, \\ ${ }^{2,3}$ Universitas Muhammadiyah Surakarta \\ 1'budiwinarno78@yahoo.com; ${ }^{2 k d 255 @ u m s . a c . i d ; ~}{ }^{3}$ liekums@gmail.com
}

Diterima: September 2020; Disetujui: Desember 2020

\begin{abstract}
Trade is a form of economic activity that has an effect on increasing the economy of a region. The availability of place, time, and goods is not a problem in trade, because the touch of technology is one of the solutions. Technology in buying and selling makes it easier for sellers and buyers to make transactions without meeting and based solely on the principle of good faith. Regarding the problems that occurred in the research process, several respondents admitted that the problems that often arise came from the traders. Because traders are often late in making payments. Small problems that often arise, for example the goods are damaged or unsuitable, if the goods are defective, it is the responsibility of the supplier. The use of oral agreements in buying and selling becomes a habit that cannot be abandoned by Klewer Market traders, even though they are aware that their position is weak if there are legal problems in its implementation. The conclusion is that the unwritten agreement entered into by a Trader with a supplier of goods at Klewer Market is still valid and binding on both parties but is weak in terms of proof in case of a civil dispute. On the other hand, we try to review the application of the principles of good faith in oral agreements between traders and suppliers of goods based on local wisdom.
\end{abstract}

Keywords: default, good faith, oral agreement.

Abstraksi. Perdagangan merupakan bentuk kegiatan ekonomi yang memberikan pengaruh dalam meningkatkan perekonomian suatu daerah. Ketersediaan tempat, waktu, maupun barang tidak menjadi masalah dalam perdagangan, karena sentuhan teknologi menjadi salah satu solusinya. Teknologi dalam jual beli mempermudah penjual dan pembeli melakukan transaksi tanpa bertemu dan hanya berdasar pada asas iktikad baik. Mengenai permasalahan yang terjadi dalam proses penelitian beberapa responden mengaku masalah yang sering muncul berasal dari pihak pedagang. Karena pedagang sering telat dalam melakukan pembayaran. Masalah kecil yang sering timbul misalnya barangnya rusak atau tidak sesuai, kalau barangnya cacat, itu menjadi tanggung jawab penyuplai. Penggunaan perjanjian lisan dalam jual beli menjadi kebiasaan yang tidak bisa ditinggalkan oleh pedagang Pasar Klewer, walaupun mereka sadar bahwa posisi mereka lemah apabila terjadi permasalahan hukum dalam pelaksanaannya. Kesimpulan yang diperoleh bahwa perjanjian tidak tertulis yang dilakukan oleh Pedagang dengan Penyuplai barang di Pasar Klewer tetap sah dan mengikat kedua belah pihak, akan tetapi lemah dalam hal pembuktian apabila terjadi sengketa perdata. Di satu sisi lainnya kita mencoba meninjau dari penerapan asas iktikad baik dalam perjanjian lisan antara pedagang dengan penyuplai barang berdasarkan local wisdom.

Kata Kunci: iktikad baik, perjanjian lisan, wanprestasi. 


\section{PENDAHULUAN}

Dewasa ini, penggunaan digital marketing telah menjadi alat untuk memberikan kemudahan dalam bertransaksi. Dengan perkembangan teknologi yang seperti itu, masih ada beberapa masyarakat yang melestarikan tata cara berdagang secara konvensional dengan mempertahankan nilai-nilai local wisdom dalam bertransaksi jual beli. Sistem perdagangan modern maupun konvensional sebenarnya hanya sebuah kebiasaan yang dibangun oleh orang-orang yang melaksanakan kegiatan perdagangan tersebut. Hal terpenting bukanlah sistem perdagangan yang dipakai dalam bertransaksi, akan tetapi satu hal yang tidak boleh dilupakan bahwa apapun transaksinya pastilah didasari dengan apa yang dinamakan perjanjian, baik itu tertulis maupun lisan. Seperti halnya yang diungkapkan oleh R. Subekti, bahwa perjanjian diartikan sebagai suatu peristiwa dimana ada seorang berjanji kepada seorang lain atau dua orang itu saling berjanji untuk melaksanakan sesuatu hal, dari peristiwa ini, timbullah suatu hubungan antara dua orang tersebut yang dinamakan "perikatan". Oleh karena itu perjanjian menerbitkan suatu perikatan antara dua orang yang membuatnya. [Subekti, 1996:22]

Menurut Black's Law Dictionary, perjanjian adalah suatu persetujuan antara dua orang atau lebih. Perjanjian ini menimbulkan sebuah kewajiban untuk melakukan atau tidak melakukan sesuatu secara sebagian. Inti definisi yang tercantum dalam Black's Law Dictionary adalah bahwa kontrak dilihat sebagai persetujuan dari para pihak untuk melaksanakan kewajiban, baik untuk melakukan atau tidak melakukan secara sebagian. [Herniwati, 2015:177] Dalam pasal 1313 KUHPerdata diatur bahwa suatu perjanjian merupakan suatu perbuatan dengan mana satu orang atau lebih mengikatkan dirinya terhadap satu orang lainnya. [Subekti, 2009] Pasal ini menerangkan secara sederhana tentang pengertian perjanjian yang menggambarkan tentang adanya dua pihak yang saling mengikatkan diri. Sedangkan menurut Sudikno Mertokusumo, perjanjian adalah suatu hubungan hukum antara dua pihak atau lebih berdasarkan kata sepakat untuk menimbulkan akibat hukum. Maksudnya, kedua pihak tersebut sepakat untuk menentukan peraturan atau kaidah yang mengikat mereka untuk ditaati dan dilaksanakan. [Herniwati, 2015:177] Berdasarkan pendapat-pendapat tersebut dapat disimpulkan bahwa perjanjian merupakan hubungan hukum antara dua pihak atau lebih berdasarkan kata sepakat untuk menimbulkan hak dan kewajiban.

Di dalam pelaksanaan sebuah perjanjian, terkandung asas-asas yang penting dalam pemenuhan unsur-unsurnya. Syarat-syarat sah sebuah perjanjian sebagaimana tercantum dalam Pasal 1320 KUHPerdata, yang meliputi: a) kesepakatan; b) kecakapan; c) suatu hal tertentu; d) sebab yang dihalalkan. Keempat syarat tersebut yang menentukan sah atau tidaknya perjanjian, apabila tidak terpenuhi salah satunya maka akan mengakibatkan tidak sahnya suatu perjanjijan. [Subekti, 2009] Tidak hanya syarat yang menentukan sebuah akibat hukum dari suatu perjanjian melainkan asas-asas yang ada dalam perjanjian seperti asas konsensualisme, asas kebebasan berkontrak, asas pacta sunt servanda, asas itikad baik (kepercayaan), maupun asas kepribadian (personalitas). [Subekti, 2009] Dari asas-asas yang muncul dalam perjanjian, asas itikad baik menjadi asas yang penting dalam menentukan pelaksanaan suatu perjanjian. Asas ini 
tertuang di dalam pasal 1338 ayat (3) KUHPerdata yang berbunyi, "Perjanjian harus dilaksanakan dengan itikad baik." [Gemala, 2006:37-38]. Asas ini mengandung pengertian bahwa para pihak dalam suatu perjanjian harus melaksanakan substansi kontrak atau prestasi berdasarkan kepercayaan atau keyakinan yang teguh serta kemauan baik dari para pihak agar tercapai tujuan perjanjian. [Rahmani, 2008:99]

Asas yang tercantum dalam pasal 1338 ayat (3) KUHPerdata juga harus dipenuhi [Subekti, 2009] dalam setiap perjanjian. Asas itikad baik merupakan asas bahwa para pihak yaitu pihak kreditur dan debitur harus melaksanakan substansi kontrak berdasarkan kepercayaan atau keyakinan yang teguh atau kemauan baik dari para pihak. Keharusan dalam pasal tersebut memberikan pengertian bahwa itikad baik itu wajib dilaksanakan oleh para pihak dalam perjanjian. Asas itikad baik ini dapat dibedakan atas itikad baik yang subjektif dan itikad baik yang objektif. Itikad baik dalam pengertian yang subjektif dapat diartikan sebagai kejujuran seseorang atas dalam melakukan suatu perbuatan hukum yaitu apa yang terletak pada sikap batin seseorang pada saat diadakan suatu perbuatan hukum. Sedangkan itikad baik dalam pengertian yang objektif dimaksudkan adalah pelaksanaan suatu perjanjian yang harus didasarkan pada norma kepatutan atau apa yang dirasakan patut dalam suatu masyarakat. Asas itikad baik dalam hukum Islam berkaitan erat dengan asas kepercayaan. Tidak berbeda dengan asas itikad baik dalam KUHPerdata, maka asas kepercayaan tersebut mengandung pengertian bahwa para pihak dalam suatu perjanjian harus melaksanakan substansi kontrak atau prestasi berdasarkan kepercayaan atau keyakinan yang teguh serta kemauan baik dari para pihak agar tercapai tujuan perjanjian. [Dwi, 2014:88]. Perjanjian antara penyuplai barang dan pedagang di Pasar Klewer Surakarta menjadi salah satu hal mendasarkan asas itikad baik dalam pelaksanaannya. Di dalam melakukan transasksi antara pedagang pasar klewer dengan para penyuplai barang, hal yang banyak terjadi adalah perjanjian lisan tanpa adanya penuangan dalam dokumen tertulis, dan perjanjian ini hanya didasarkan pada itikad baik dari masing-masing pihak. Menjadi suatu hal yang cukup merugikan kedua belah pihak apabila ada permasalahan hukum yang terjadi di tengah-tengah perjanjian atau sering kita kenal dengan wanprestasi. Hal ini terus menerus terjadi dalam pelaksanaan kebanyakan transaksi antara pedagang dengan penyuplai barang, dikarenakan keengganan atau kurangnya kesadaran kedua belah pihak dalam mengikat perjanjian mereka ke dalam suatu bentuk perjanjian yang baku beserta akibat hukumnya. Masalah pembuktian menjadi salah satu hal yang patut diperhitungkan dalam perjanjian lisan (non kontraktual), bahkan sampai dengan tidak dipenuhinya salah satu hak dan kewajiban dari masingmasing pihak juga sulit untuk dibuktikan. Namun terkait dengan pembuktian adanya perjanjian lisan tersebut, di dalam rumusan Pasal 1865 KUHPerdata disebutkan bahwa, "barang siapa mendalilkan sesuatu hak harus membuktikannya." Selanjutnya di dalam rumusan Pasal 1866 KUHPerdata juga disebutkan bahwa, "alat bukti yang dapat dipakai untuk membuktikan suatu dalil terdiri atas: bukti tulisan, bukti saksi, persangkaan, pengakuan dan sumpah. [Subekti, 2009]

Perjanjian pedagang dan penyuplai barang di Pasar Klewer selama ini dilakukan secara non kontraktual atau lisan. 
Perjanjian non kontraktual yang dipercaya adalah perkataan yang diucapkan oleh para pihak. Perjanjian tersebut dilaksanakan berdasarkan kata sepakat dan itikad baik antara para pihak. Perjanjian antara pedagang dan penyuplai barang secara lisan dilakukan hanya dengan perkataan para pihak dan itikad baik saja. Apabila proses tersebut tetap dipertahankan, maka akan terjadi berbagai masalah salah satunya wanprestasi. Immanuel Kant, seorang ahli filsafat Jerman (1724-1820) berpendapat bahwa sesuatu itu yang secara absolut baik, adalah keinginan baik (good will) itu sendiri. Jadi jelas, dalam hal ini pertanyaannya adalah "bagaimana dapat diidentifikasi keinginan baik tersebut?" Kant menjawabnya dengan mengatakan bahwa ada hukum moral yang rasional, yang bisa diidentifikasi berdasarkan akal. [Ridwan, 2004: 130-133] Itikad baik dalam hukum perjanjian merupakan doktrin atau asas yang berasal dari ajaran bona fides dalam Hukum Romawi. Itu sebabnya asas itikad baik memang lebih memiliki kedekatan dengan Sistem Civil Law ketimbang dengan Sistem Common Law. Fides berarti sumber yang bersifat religius, yang bermakna kepercayaan yang diberikan seseorang kepada orang lainnya, atau suatu kepercayaan atas kehormatan dan kejujuran seseorang kepada orang lainnya. Bona fides mensyaratkan adanya itikad baik dalam perjanjian yang dibuat oleh orang-orang Romawi.

Contoh bahaya perjanjian lisan yaitu dalam Kasus perkara wanprestasi pada putusan pengadilan Negeri Yogyakarta Nomor 44/PDt.G/2015/PPN.Yyk. Putusan tersebut mengenai perkara wanprestasi, antara Subagyo sebagai Penggugat dan Ary Kalista sebagai Tergugat. Ary Kalista digugat atas dasar telah melakukan wanprestasi terhadap perjanjian lisan yang dibuat oleh Ary Kalista dan Subagyo. Ary Kalista melakukan pembelaan dengan mendalilkan bahwa tidak pernah membuat perjanjian lisan tersebut. Namun hakim memutuskan bahwa Ary Kalista melakukan wanprestasi. Perjanjian lisan memiliki kekuatan hukum untuk menyatakan seseorang melakukan wanprestasi, selama perjanjian lisan tersebut terbukti telah dibuat oleh para pihak dan telah sesuai dengan syarat sahnya perjanjian dalam Pasal 1320 KUH Perdata [Billy, Tuhana, 2016:113]

Berdasarkan uraian tersebut di atas, maka peneliti tertarik untuk mengambil penelitian dengan Judul "Perjanjian Lisan (Non Kontraktual) dan Penerapan Asas Iktikad Baik Dalam Transaksi Antar Pedagang Dengan Penyuplai Barang (Studi Kasus Di Pasar Klewer Surakarta)". Maka sebelum melakukan pembahasan lebih lanjut perlu ditentukan masalah apa saja yang akan diangkat dalam penelitian ini. Rumusan masalah yang akan penulis angkat dalam penelitian ini adalah: 1) Bagaimana penerapan asas itikad baik dalam perjanjian lisan antar pedagang dengan penyuplai barang berdasarkan local wisdom? 2) Apakah iktikad baik dapat menyelesaikan terjadinya wanprestasi dalam perjanjian lisan antara pedagang dan penyuplai barang di Pasar Klewer Surakarta?

\section{METODE PENELITIAN}

Penelitian ini mendasarkan pada penelitian hukum yang dilakukan dengan pendekatan non-doktrinal yang kualitatif. Dengan demikian di dalam penelitian ini akan terlihat keterkaitan antara faktor hukum dengan faktor-faktor di luar hukum yang berkaitan dengan objek yang diteliti. Penelitian ini dilakukan dengan mengkaji data primer yang berasal dari lokasi penelitian yaitu Pasar Klewer sebagai 
tempat dikajinya permasalahan yang berkaitan tentang penerapan asas kepercayaan dalam transaksi antara pedagang dengan penyuplai barang.Penentuan lokasi penelitian ini dilakukan secara purposive, berdasarkan berbagai pertimbangan yaitu : pertama, karena di daerah inimemungkinkan untuk dilakukan penelitian yang berkaitan dengan permasalahan mengenai penerapan asas itikad baik dalam transaksi antara pedagang dengan penyuplai barang di Pasar Klewer. Kedua, penentuan lokasi di pasar banyak ditemukan pelaksanaan perjanjian antara pedagang dengan penyuplai barang baik secara sah maupun tidak sah. Ketiga, penentuan lokasi di Dinas Perdagangan, karena Pasar Klewer berada di bawah Dinas Perdagangan.

Spesifikasi kajian penelitian ini yaitu menggambarkan secara jelas (dengan tidak menutup kemungkinan pada taraf tertentu juga akan mengeksplanasikan/ memahami) tentang berbagai hal terkait dengan objek yang diteliti, yaitu penerapan asas itikad baik dalam perjanjian lisan antar pedagang dengan penyuplai barang berdasarkan local wisdom dan kekuatan mengikat dari asas itikad baik dalam perjanjian lisan antara pedagang dan penyuplai barang di Pasar Klewer Surakarta apabila terjadi wanprestasi. Sumber data yang diperlukan dalam penelitian ini diperoleh dari dua jenis data yang berasal dari dua sumber yang berbeda, yaitu Data Primer dan Data Sekunder. Data primer merupakan data-data yang berasal dari sumber data utama, berwujud tindakan-tindakan sosial dan katakata, yaitu dari pihak-pihak yang terlibat dengan objek yang diteliti (sesuaikan dengan objek masing). [Lexy: 112] Beberapa informan yang memenuhi kriteria dalam penelitian ini yaitu : (1) mereka yang menguasai dan memahami fokus permasalahan melalui proses enkulturasi; (2) mereka yang terlibat dalam kegiatan yang tengah diteliti dan; (3) mereka yang memiliki kesempatan dan waktu yang memadai untuk dimintai informasi. Untuk itu yang diperkirakan dapat menjadi informan awal adalah : (1) penyuplai barang di Pasar Klewer; (2) pedagang di Pasar Klewer; (3) Lurah Pasar Klewer; (4) Bidang Pengelolaan Pendapatan Dinas Perdagangan Kota Surakarta. Kerangka penelitian dapat dilihat seperti Gambar 1. dibawah ini:

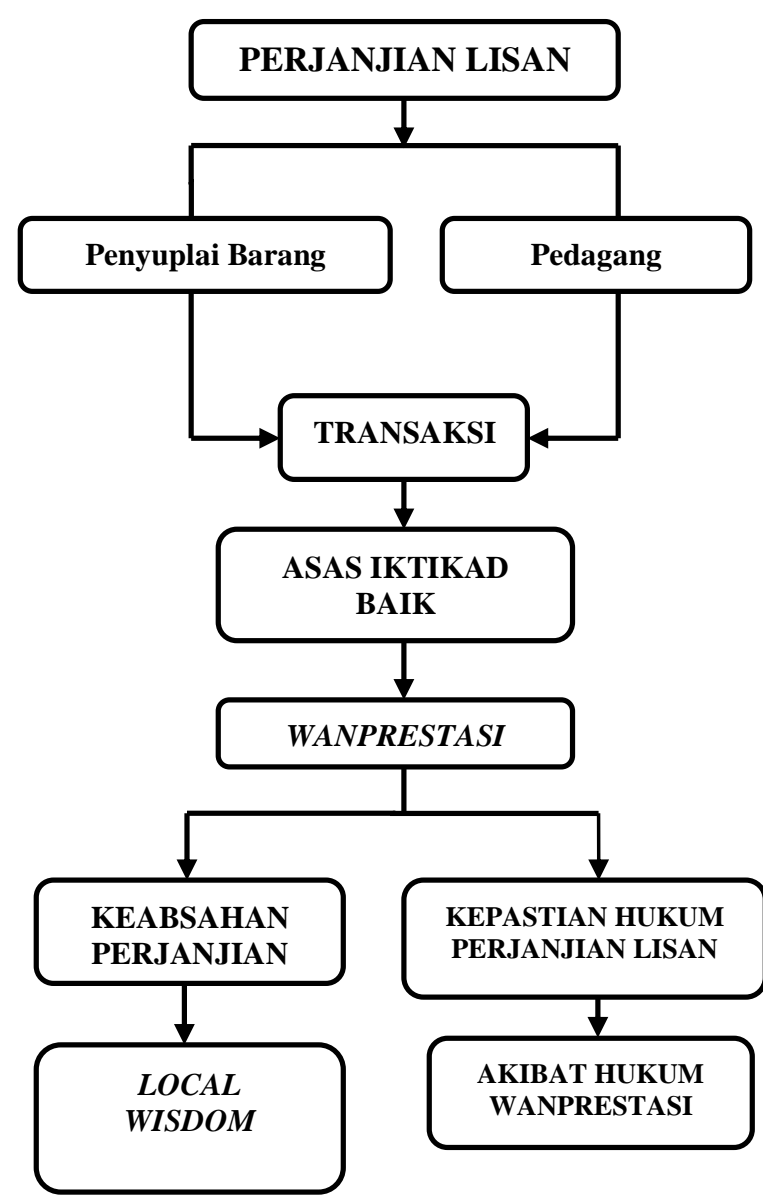

Gambar 1. Kerangka Teoritik Sumber: Analisis Penelitian

Sedangkan Data sekunder merupakan data yang berasal dari bahan-bahan pustaka, terdiri dari Dokumen-dokumen tertulis, yang bersumber dari peraturan perundangundangan di Indonesia, artikel ilmiah, 
buku-buku literatur, dokumen-dokumen resmi, arsip dan publikasi dari lembagalembaga yang terkait serta dokumendokumen yang bersumber dari data-data statistik, dapat dikeluarkan oleh instansi pemerintah, maupun oleh swasta terkait dengan pelaksanaan perjanjian tertulis, perjanjian lisan, dan asas iktikad baik. Datadata yang diperlukan dalam penelitian ini, akan dikumpulkan melalui tiga cara, yaitu : melalui wawancara, observasi dan studi kepustakaan, yang dilakukan dengan tahaptahap sebagai berikut : Pada tahap awal, akan dilakukan studi kepustakaan dengan cara mencari, mengiventarisasi dan mempelajari peraturan perundang-undangan yaitu KUHPerdata, yurisprudensi yaitu Putusan Pengadilan Negeri Yogyakarta Nomor 44/PDT.G/2015/PN.YYK, dan doktrin-doktrin, dan data-data sekunder lain yang berkaitan dengan fokus permasalahannya. Kemudian akan dilakukan wawancara secara intensif dan mendalam terhadap para informan, dan observasi yang tidak terstruktur, ditujukan terhadap beberapa orang informan dan berbagai situasi. Kedua cara yang dilakukan secara simultan ini dilakukan dengan maksud untuk memperoleh gambaran yang lebih terperinci dan mendalam, tentang apa yang tercakup di dalam berbagai permasalahan yang telah ditetapkan pada satu fokus permasalahan tertentu, dengan cara mencari kesamaankesamaan elemen yang ada dalam masingmasing bagian dari fokus permasalahan tertentu, yang dilanjutkan dengan mencari perbedaan-perbedaan elemen yang ada dalam masing-masing bagian dari fokus permasalahan tertentu.

Setelah semua tahapan analisis tersebut dilakukan, pada tahapan akhir akan dilakukan penafsiran data yaitu dimana teori-teori yang ada diaplikasikan ke dalam data, sehingga terjadi suatu dialog antara teori di satu sisi dengan data di sisi lainnya. Malalui cara ini, selain diharapkan dapat dihasilkan beberapa asumsi sebagai dasar untuk menunjang, memperluas atau menolak, teori-teori yang sudah ada tersebut, diharapkan juga akan ditemukan berbagai fakta empiris yang relevan dengan kenyataan yang ada di masyarakat.

Menurut Sugiyono (2010: 335), yang dimaksud dengan teknik analisis data adalah proses mencari data, menyusun secara sistematis data yang diperoleh dari hasil wawancara, catatan lapangan, dan dokumentasi, dengan cara mengorganisasikan data ke dalam kategori, menjabarkan ke dalam unit-unit, melakukan sintesis, menyusun ke dalam pola memilih mana yang penting dan yang akan dipelajari, dan membuat kesimpulan sehingga mudah dipahami oleh diri sendiri maupun orang lain. Teknik anaisis data yang digunakan dalam penelitian ini adalah analisis data induktif. Analisis data induktif adalah penarikan kesimpulan yang berangkat dari fakta-fakta khusus, untuk kemudian ditarik kesimpulan secara umum.

\section{HASIL DAN PEMBAHASAN}

\section{Penerapan Asas Iktikad Baik Dalam} Perjanjian Lisan Antar Pedagang Dengan Penyuplai Barang Berdasarkan Local Wisdom

\section{Gambaran Umum Pasar Klewer}

Berdasarkan hasil penelitian yang dilakukan mengenai penerapan asas iktikad baik dalam perjanjian lisan antar pedagang dengan penyuplai barang berdasarkan local wisdom. Sebelum menjawab permasalahan mengenai penerapan asas iktikad baik dalam perjanjian lisan antar pedagang dengan penyuplai barang berdasarkan local wisdom. Bahwa, Pasar Klewer merupakan pasar tekstil terbesar di Kota Surakarta. 
Pasar yang letaknya bersebelahan dengan Keraton Surakarta, merupakan pusat perbelanjaan kain batik yang menjadi rujukan para pedagang dari Yogyakarta, Surabaya, Semarang, dan kota-kota lain di Pulau Jawa. Bangunan pasar dua lantai ini menampung 1.467 pedagang dengan jumlah kios sekitar 2.064 unit. Pada zaman pendudukan Jepang di Indonesia, kawasan di Pasar Klewer merupakan tempat pemberhentian kereta api yang digunakan sebagai tempat berjualan para pedagang pribumi. Oleh karena digunakan sebagai tempat berjualan, kawasan tersebut terkenal dengan sebutan Pasar Slompretan. Pasar Slompretan ini merupakan tempat para pedagang kecil yang menawarkan barang dagangan berupa kain batik yang diletakkan dipundaknya sehingga tampak menjuntai tidak beraturan atau berkleweran jika dilihat dari kejauhan. Dari barang dagangan kain batik yang berkleweran itu, pasar ini terkenal dengan nama Pasar Klewer. Pasar Klewer mulai berkembang pada tahun 1942-1945, dan semakin berkembang hingga tahun 1968. Kemudian dibangunlah bangunan pasar bertingkat permanen pada 9 Juni 1970 untuk menampung para pedagang yang diresmikan oleh Presiden Soeharto [wikipedia, sejarah pasar klewer]

Pasar Klewer menyediakan berbagai macam jenis kain dan pakaian mulai dari pakaian anak-anak, dewasa, orang tua, pakaian resmi, pakaian sekolah, pakaian kemeja wanita, dan pakaian santai. Selain itu, terdapat kaos, jaket, dasi, kain bahan katun hingga sutra. Namun yang menarik di Pasar Klewer adalah adanya berbagai macam jenis batik. Di antaranya batik tulis Solo, batik cap, batik antik keraton, batik putri Solo, dan ada berbagai jenis batik dari kota-kota lainnya. Di pasar ini juga tersedia kain batik untuk baju, seprai, sarung, bantal dan aksesori-aksesori bermotif batik. Selain terkenal dengan pusat batik, pasar ini juga menyediakan makanan, kerajinan, pernakpernik, barang elektronik, emas dan peralatan dapur. Ada juga kerajinan khas masyarakat Solo yang berkualitas ekspor, seperti cermin kayu ukir, kaca ukir, dan berbagai cenderamata berbahan dasar kaca. Pasar Klewer berada di bawah Dinas Perdagangan Kota Surakarta yang berdasarkan Peraturan Daerah Kota Surakarta Nomor 10 Tahun 2016 tentang Pembentukan dan Susunan Perangkat Daerah Kota Surakarta dan Peraturan Walikota Surakarta Nomor 27 - C Tahun 2016, susunan organisasinya salah satunya adalah bidang pasar yang membawahkan seksi pembinaan dan pemeliharaan [jdih.surakarta.go.id].

\section{Hasil Penelitian Perjanjian Lisan Antar Pedagang Dengan Penyuplai Barang Berdasarkan Local Wisdom}

Perjanjian tanpa bukti tertulis ini banyak dijumpai dalam transaksi antara penyuplai barang dengan pedagang di Pasar Klewer yang hanya berlandaskan asas iktikad baik dan kepercayaan tanpa adanya perjanjian tertulis di bawah tangan. Asas iktikad baik sangat penting dalam membuat perjanjian, karena iktikad baik dapat menimbulkan keyakinan bagi para pihak bahwa perjanjian akan dilaksanakan oleh para pihak tersebut. Oleh karena itu, para pihak terlebih dahulu harus menumbuhkan kepercayaan di antara mereka bahwa satu sama lain akan memenuhi janji yang disepakati atau melaksanakan prestasinya di kemudian hari. Dengan kepercayaan dan iktikad baik, kedua pihak mengikatkan dirinya kepada kontrak yang mempunyai kekuatan mengikat sebagai undang-undang sebagaimana ditentukan dalam Pasal 1338 ayat (1) KUHPerdata. 
Dari hasil wawancara yang dilakukan oleh penulis, ditemukan hasil penelitian bahwa kesepakatan lisan antara pedagang Pasar Klewer dengan penyetor barang dengan hanya berdasarkan asas saling percaya dan asas iktikad baik adalah suatu hal yang wajar dan sudah menjadi kebiasaan atau adat yang sehari-hari dilakukan oleh hampir semua para pedagang yang berjualan di Pasar Klewer. Menurut pedagang Pasar Klewer yang bernama Wiwis, dia mengaku sudah berjualan sejak Pasar Klewer mulai buka yakni pada tahun 2017. Dalam berjualan kain dan pakaian sehari-hari, Wiwis mengaku banyak mengambil stok kain dari Sragen menyesuaikan dengan barang dagangannya yang sebagian besar merupakan batik Sragen. Namun sebagian lagi kain yang dijualnya juga merupakan produksi sendiri, artinya tidak semua mendapatkan stok dari penyuplai di Sragen. Wiwis mengambil kain yang akan dijual dengan penyuplai yang sudah menjadi langganannya sejak lama dari Sragen. Dalam bertransaksi, Wiwis menjelaskan memakai nota tertulis sekedarnya dengan metode pembayaran dibayarkan secara cash dan ada yang dibayarkan secara bertahap. Hal ini sebagaimana yang dijelaskan sebagai berikut: "Iya karena yang kita jual kan batik Sragen jadi kebanyakan ngambil kainnya dari Sragen. Pake nota tertulis, untuk pembayarannya ada yang langsung cash ada yang bertahap"

Wiwis kembali menjelaskan bahwa jika terjadi cacat barang yang diambil dari penyuplai, maka untuk mengatasi permasalahan kecil tersebut, cukup diselesaikan dengan metode tukar barang. Hal ini sebagaimana yang dijelaskan sebagai berikut: "Ya kalau ada yang cacat, tinggal ditukar. Jadi dalam berhubungan dengan supplier tidak terlalu kaku." Dalam menerima barang yang disuplai dari luar, Wiwis mengaku juga menerima barang titipan dari penyuplai lain dengan ketentuan metode pembayaran juga akan menyesuaikan dengan pihak pedagang dalam hal ini Wiwis. Wiwis mengaku hasil penjualan setiap bulan sudah dapat mencukupi kebutuhan hidupnya dari sebagian kain hasil dari produksi sendiri yang dijual. Pembayaran kain yang disuplai dari luar menyesuaikan dengan hasil penjualan per bulan dan biasanya bisa ditutup atau dibayarkan langsung ke penyuplai dengan jangka waktu 1 bulan. Jumlah penyuplai barang di kios Ibu Wiwis mencapai 15 orang penyuplai lebih. Mengenai harga, beliau mengaku untuk kisaran harga batik printing maupun tulis mulai dari harga Rp 60.000,00 hingga Rp $850.000,00$, tergantung proses produksi atau pembuatannya. Penghasilan kotor bisa mencapai Rp 60.000.000,00 setiap bulan. Mengenai kondisi pasar yang sekarang beliau mengaku sudah berbeda jauh dengan kondisi pasar sebelum terjadi peristiwa kebakaran yang cenderung lebih ramai.

Pedagang Pasar Klewer lainnya yang berhasil ditemui oleh penulis adalah $\mathrm{Bu}$ Tri. Dalam berhubungan dengan penyuplai barang, Bu Tri mengaku transaksi yang dijalankan dengan memakai nota biasa dengan metode pembayaran ada yang langsung ada yang tidak langsung. "iya pake nota, biasanya nge-bon dulu. Ada yang langsung ada yang ndak langsung pembayarannya." Kain batik yang dijual oleh Bu Tri 100\% berasal dari penyuplai. Beliau menjelaskan tidak pernah menemukan masalah yang serius yang berasal dari penyuplai barang. Misalnya di kemudian hari, ditemukan cacat barang yang disuplai, barang otomatis kembali untuk ditukar sesuai dengan perjanjian di awal yang telah terbentuk. Ketika ditanya 
mengenai penghasilan, $\mathrm{Bu}$ Tri mengaku penghasilannya tidak menentu dikarenakan sepi pembeli. Beliau mengaku kebijakan yang diatur untuk pedagang yang ada di Pasar Klewer dengan luas kios yang lumayan sempit bersumber dari Pemerintah Kota Surakarta selain Dinas Perdagangan Surakarta. Hal ini sejak peristiwa kebakaran yang menimpa Pasar Klewer pada tahun 2017 lalu. Sehingga semenjak itu, luas kios yang dulunya lebar sekarang menjadi sempit untuk masing-masing penjual. Akibatnya, omset penjualannya turun drastis.

Pedagang lain yang berhasil diwawancarai penulis adalah Ibu Winda. Ibu Winda mengaku $75 \%$ barang yang dijualnya adalah produksi sendiri yang merupakan mukena, sedangkan kain mengambil dari penyuplai luar. Mengenai kain yang diambil dari penyuplai adalah jenis rayon. Hal ini sebagaimana yang dituturkan sebagai berikut: "Jadi ada beberapa item yang mengambil dari produsen lain. Sementara selebihnya merupakan produksi sendiri. Kalo batik ada motif ada kembang kalo kita pake rayon." Beliau menjelaskan lebih lanjut, biasanya pembayaran supplier ada yang memakai giro ada yang sistem bayarnya mingguan atau harian. Ada juga yang belanja kontan atau cash sebagaimana yang dijelaskan berikut. "kalo yang sistemnya ndak kontan atau sistemnya hutang barang, ya sistem pembayarannya kalo ndak giro pakainya sistem mingguan kalo nggak harian." Ibu Winda dalam menjelaskan transaksi yang biasa dilakukan antara pedagang Pasar Klewer dengan supplier, ada yang tidak pakai nota tertulis, sehingga jika terjadi permasalahan merupakan resiko yang harus siap diambil oleh pedagang. "Bukti cuma nota itu, dan setiap kita bayar kan tertulis. Setiap kita bayar, kita tanda tangan, kalo sistemnya cicilan. Tapi kalo sistem giro, begitu itu cair nota putih diberi ke kita. Kalo belum cair tetep kita pegang nota merah. Kalo sistem cicilan setiap kita bayar kita tanda tangan. Ya buktinya ya hanya nota itu." Ibu Winda mengaku dalam bertransaksi dengan supplier dengan berlandaskan pada kepercayaan dan iktikad baik. Sehingga sebelumnya sudah ada rasa saling percaya dan supplier yang dipakai adalah supplier langganan. "Misalkan dikasih waktu 2 bulan, ya terus kita ngangsur selama waktu itu. Tapi ya namanya orang kerja pasti juga ada molornya, kadang bisa 2 bulan lebih, tapi angsuran tetap jalan terus."

Mengenai permasalahan yang terjadi, beliau mengaku permasalahan malah kebanyakan datang dari pihak pedagang. Karena pedagang sering molor dalam melakukan pembayaran. Jika dari penyuplai malah jarang ada yang bermasalah. Masalah kecil yang sering timbul misalnya barangnya rusak atau tidak sesuai. "Sehingga kalau dari penyuplai masalah paling $10-20 \%$, kebanyakan dari pedagang yang sering molor dalam membayar. Kalau barangnya cacat, itu menjadi tanggung jawab penyuplai." Ibu Winda juga mengakui bahwa Pasar Klewer sudah tidak seramai dulu lagi semenjak peristiwa kebakaran. Salah satu penyebabnya adalah datangnya pedagang-pedagang lain setiap Hari Senin Kamis dari pekalongan dan dari daerah-daerah lainnya yang berjualan di luar dengan bermodalkan mobil di parkiran. Hal ini menyebabkan banyak pedagangpedagang besar atau bakul besar sudah tidak masuk pasar karena langsung bayar kontan dengan pedagang aslinya. Sehingga pedagang-pedagang di Pasar Klewer sekarang hanya menerima sisanya atau ecerannya saja. Sebagaimana yang dijelaskan Ibu Winda sebagai berikut: 
"Untuk keramaian sudah tidak merata, sekarang yang diharapkan sudah tidak bakul-bakul besar tapi pelancong karena memang sudah sepi. Pembeli lain lebih suka datang ke Pusat Grosir Surakarta (PGS) dan tempat lain. Memang untuk kenyamanan pedagang lebih nyaman sekarang, tapi untuk keramaian lebih bagus dulu dari sisi tingkat penghasilan yang didapat. Sehingga penjualan di Pasar Klewer sudah tidak maksimal."

Menurutnya dirapikan belum tentu lebih baik termasuk dari segi pengaturan kios. Mengenai keluhan-keluhan pedagang juga jarang yang ditanggapi serius oleh
Pemerintah Kota Surakarta. Dari segi penghasilan Ibu Winda setiap bulan sudah mencukupi, sebab dari barang yang dijual merupakan barang yang jarang dijual yakni kain mukena, selain itu juga produksi sendiri sehingga bisa bersaing harga. Tidak seperti pedagang lain sebagian besar menjual kain batik sehingga tidak bisa bersaing harga dan sebagian besar para pedagang besar mengambil barang langsung dari pedagang Pekalongan yang datang ke Pasar Klewer setiap hari tertentu. Berdasarkan hasil wawancara diatas, maka penulis akan mencoba menyusun hasil wawancara dalam Tabel 1. sebagai berikut:

Tabel 1.

Rekap Wawancara Pedagang Pasar Klewer

\begin{tabular}{|c|c|c|c|c|c|c|}
\hline No & $\begin{array}{c}\text { Nama } \\
\text { Pedagang }\end{array}$ & $\begin{array}{c}\text { Jenis } \\
\text { Dagangan }\end{array}$ & $\begin{array}{c}\text { Bukti } \\
\text { Transaksi }\end{array}$ & $\begin{array}{c}\text { Cara } \\
\text { Pembayaran }\end{array}$ & $\begin{array}{c}\text { Permasa } \\
\text { lahan yang } \\
\text { terjadi }\end{array}$ & $\begin{array}{c}\text { Penyele saian } \\
\text { Masalah }\end{array}$ \\
\hline 1 & Wiwis & $\begin{array}{l}\text { Kain dan } \\
\text { Pakaian }\end{array}$ & $\begin{array}{l}\text { Nota } \\
\text { tertulis }\end{array}$ & $\begin{array}{l}\text { Cash dan } \\
\text { Cicilan }\end{array}$ & $\begin{array}{l}\text { Barang } \\
\text { rusak }\end{array}$ & Retur barang \\
\hline 2 & Bu Tri & Kain batik & Nota biasa & $\begin{array}{l}\text { Langsung dan } \\
\text { Tidak } \\
\text { langsung }\end{array}$ & $\begin{array}{l}\text { Barang } \\
\text { Rusak }\end{array}$ & Retur barang \\
\hline 3 & Bu Winda & $\begin{array}{l}\text { Mukena } \\
\text { dan kain }\end{array}$ & $\begin{array}{l}\text { Nota } \\
\text { tertulis }\end{array}$ & $\begin{array}{l}\text { Giro } \\
\text { mingguan } \\
\text { atau harian }\end{array}$ & $\begin{array}{l}\text { Telat } \\
\text { angsur, } \\
\text { Barang } \\
\text { rusak }\end{array}$ & $\begin{array}{l}\text { Minta } \\
\text { perpanjangan } \\
\text { waktu dan } \\
\text { retur barang }\end{array}$ \\
\hline
\end{tabular}

Sumber: Hasil Wawancara Dengan Pedagang Pasar Klewer

Dari Tabel di atas menggambarkan bahwa bukti transaksi yang menjadi kebiasaan hanya berupa nota tertulis saja tanpa disertai adanya perjanjian dalam bentuk tertulis. Kemudian dari cara pembayarannya dilakukan dengan cash, cicilan, dan giro baik secara mingguan atau harian. Sedangkan permasalahan yang sering terjadi adalah barang rusak dan telat angsuran dengan cara penyelesaiannya yaitu untuk barang rusak bisa langsung dilakukan retur kepada penyuplai barang, dan untuk masalah telat angsuran dapat diselesaikan dengan permohonan secara lisan kepada penyuplai barang untuk memberikan kompensasi perpanjangan waktu cicilan pembayaran. Selama melaksanakan transaksi dan perjanjian lisan ini tidak pernah muncul permasalahan yang kompleks karena dilandasi iktikad baik.

Analisis Penerapan Asas Iktikad Baik Dalam Perjanjian Lisan Antar Pedagang Dengan Penyuplai Barang Berdasarkan Local Wisdom

Berdasarkan hasil penelitian yang didapatkan penulis dari beberapa transaksi yang dilakukan oleh pedagang Pasar 
Klewer dengan penyuplai barang, dapat disimpulkan bahwa sebagian besar transaksi antara pedagang dan penyuplai barang dilakukan berlandaskan pada asas saling percaya. Asas kepercayaan (vertrouwensleer), sebagaimana dijelaskan oleh J.J.M. Maeijer yang dikutip dari Herlien Budiono, yang menjelaskan bahwa terjadinya hubungan hukum bukan dilandaskan pada kehendak masing-masing pihak namun lebih kepada kepercayaan yang timbul secara otomatis atas hal yang sudah menjadi kesepakatan bersama. Sehingga yang ditekankan lebih pada kepercayaan yang timbul bagi para pihak. Di dalam kepercayaan secara tidak langsung terkandung muatan-muatan baik itu nilai, prinsip-prinsip dan norma-norma sosial yang harus disepakati dalam suatu masyarakat. Sehingga para pihak memiliki rasa percaya satu sama lain yang kemudian menyertai timbulnya akibat-akibat hukum yang dapat dipertanggungjawabkan atas apa yang dikehendaki satu sama lain dalam hal berjalannya perjanjian yang dilakukan atas dasar saling percaya. [Syaifuddin, 2012:100]

Berdasarkan transaksi yang dilakukan pedagang Pasar Klewer dan penyuplai barang, sudah sesuai dengan asas kepercayaan, dimana setelah apa yang disepakati bersama dinyatakan secara lisan oleh kedua belah pihak, kemudian timbul rasa saling percaya dengan dibuktikan nota tertulis seadanya dan tidak dinyatakan dalam perjanjian atau kontrak tertulis secara resmi. Ada juga pedagang Pasar Klewer yang mendasarkan pada rasa saling percaya saja tanpa perlu ada nota, dengan mekanisme hanya sebatas titip barang kemudian metode pembayaran kepada supplier berdasarkan kesepakatan bersama dibayar secara berangsur atau bertahap. Sehingga hal ini juga bergantung pada mekanisme yang disepakati antar tiap-tiap pedagang dimana pedagang yang satu berbeda dengan pedagang yang lain. Kepercayaan dengan demikian sifatnya subjektif, dan yang diperlukan adalah penetapan kriterium psikologis. Maka dari itu, dapat terjadi suatu perjanjian menjadi absah, sekalipun adanya fakta obyektif bahwa sebenarnya salah satu pihak enggan untuk terikat, atas dasar adanya kepercayaan pihak lawannya yang dapat dibenarkan. [Herlien, 2015:398] Penerapan asas kepercayaan banyak dijadikan landasan dalam perjanjian atau dalam hal ini kontrak. Tidak hanya asas kepercayaan, asas kepribadian, asas pacta sunt servanda, asas kebebasan berkontrak juga merupakan asas-asas yang cukup penting dalam pembuatan dan pelaksanaan perjanjian atau kontrak. Hal ini termasuk dalam penerapan perjanjian yang dilakukan secara lisan tanpa adanya hal-hal yang disepakati di bawah tangan secara tertulis yang hanya mengandalkan kepercayaan saja.

Lebih lanjut mengenai asas iktikad baik tercantum dalam Pasal 1338 ayat (3) KUHPerdata yang berbunyi: "Perjanjian harus dilaksanakan dengan iktikad baik." Asas ini merupakan asas bahwa para pihak, yaitu pihak kreditur dan debitur harus melaksanakan substansi kontrak berdasarkan kepercayaan atau keyakinan yang teguh maupun kemauan baik dari para pihak. Iktikad baik merupakan salah satu asas penting dalam hukum perjanjian, tetapi makna asas iktikad baik itu sendiri masih abstrak, sehingga timbul pengertian yang berbeda-beda baik dari perspektif waktu, tempat dan orangnya, selain tidak ada makna tunggal iktikad baik, dalam praktek timbul pula permasalahan mengenai tolak ukur, dan fungsi iktikad baik tersebut [Ridwan, 2004:129]. Iktikad baik dalam perjanjian merupakan doktrin yang berasal 
dari hukum Romawi, doktrin tersebut bermula dari doktrin ex bona fides. Doktrin ini mensyaratkan adanya iktikad baik dalam kontrak. Iktikad baik dalam hukum kontrak Romawi mengacu pada tiga bentuk perilaku para pihak dalam kontrak. Pertama, para pihak harus memegang teguh janji atau perkataannya. Kedua, para pihak tidak boleh mengambil keuntungan dengan tindakan yang menyesatkan terhadap salah satu pihak. Ketiga, para pihak mematuhi kewajibannya dan berperilaku sebagai orang terhormat dan jujur, walaupun kewajiban tersebut tidak secara tegas diperjanjikan. Iktikad baik juga selalu dihubungkan dengan bunyi pasal bahwa "Perjanjian tidak hanya mengikat apa yang dengan tegas ditentukan di dalamnya, melainkan juga segala sesuatu yang menurut sifatnya perjanjian dituntut berdasarkan kepatutan, kebiasaan, atau Undang-Undang.

Jika dikaji melalui doktrin ex bona fides yang merupakan asal muasal lahirnya doktrin iktikad baik dalam perjanjian dalam hukum kontrak Romawi, maka perjanjian lisan yang dilakukan antara pedagang Pasar Klewer dengan penyuplai barang telah memenuhi standar standar perilaku masingmasing pihak dalam kontrak. [Novalia, 2015:89]. Pertama, baik dari pihak pedagang maupun penyuplai sama-sama memegang kesepakatan yang telah dibuat dari awal, dimana barang dititipkan ke pedagang untuk dijual dengan pembayaran diangsur. Hal ini terbukti dengan jangka waktu yang ditetapkan, masing-masing pihak menaati apa yang telah disepakati, pihak pedagang membayar sesuai dengan jatuh tempo yang telah ditentukan sebelumnya. Dan berlaku sama dengan metode pembayaran cash dimana, pihak pedagang langsung membayar apa yang menjadi kewajibannya setelah barang disupplai ke pasar. Kedua, para pihak tidak boleh mengambil keuntungan dengan tindakan yang menyesatkan terhadap salah satu pihak. Hal ini bersesuaian dengan perjanjian lisan yang dilakukan pedagang Pasar Klewer dengan pihak penyuplai, dimana pihak pedagang tidak mengambil keuntungan dengan menyalahi pembayaran yang harus diselesaikan kepada penyuplai, begitu juga penyuplai menyepakati aturan yang dibuat bersama, yakni menunggu hingga jatuh tempo pembayaran yang akan diselesaikan pihak pedagang. Begitu juga berkaitan dengan kualitas barang, pihak pedagang berhak melakukan pengecekan jika didapati barang yang rusak atau cacat, pihak pedagang berhak meminta barang pengganti untuk ditukar. Dengan begitu kedua belah pihak tidak berusaha mengambil keuntungan satu sama lain. Ketiga, para pihak mematuhi apa yang menjadi kewajibannya dan berperilaku sebagai orang terhormat dan jujur walaupun kewajiban tersebut tidak secara tegas dibuat dalam perjanjian. Dalam hal ini pedagang maupun penyuplai keduanya berperilaku secara jujur menyepakati apa yang sudah diperjanjian dari awal. Dalam hal kondisi barang yang di suplai, pedagang memiliki kebebasan untuk memeriksa dan mengembalikan atau menukar jika ditemukan barang dengan kualitas rendah, cacat atau rusak, sehingga kejujuran diperlihatkan oleh penyuplai barang. Begitu juga dengan pedagang, dalam melakukan pembayaran dilakukan dengan cara diangsur dan setelah batas waktu yang ditentukan, pedagang membayar dengan jujur dengan jumlah yang telah ditentukan dari awal sesuai nota yang dibuat, sehingga kedua belah pihak tidak ada yang berusaha mengkhianati satu sama lain.

Berdasarkan hasil wawancara yang dilakukan tersebut, bahwa hampir semua 
pedagang di Pasar Klewer dalam melakukan transaksi dengan penyuplai barang adalah dengan kesepakatan dalam bentuk lisan dengan berlandaskan asas iktikad baik. Dalam kesepakatan lisan yang dibuat oleh pedagang Pasar Klewer memuat tata cara, aturan, dan prinsip-prinsip moral yang secara umum sudah menjadi kebiasaan berdagang atau bertransaksi di Pasar Klewer. Jika dihubungkan dengan pembagian asas iktikad baik maka, asas iktikad baik yang dilakukan baik oleh pedagang Klewer maupun oleh penyuplai barang lebih kepada iktikad baik mutlak dengan melakukan penilaian sebelumnya yang didasarkan pada keadilan dan juga common sense (akal sehat) berdasarkan ukuran atau penilaian yang objektif bahwa penyuplai barang mempercayakan barangnya kepada penjual dengan sistem pembayaran bertahap sebab memang diketahui sekarang kondisi Pasar Klewer tidak terlalu ramai dan tidak terlalu menguntungkan bagi para pedagang di dalam pasar, hal ini dapat dinilai dengan akal sehat dan unsur keadilan bagi para pedagang sendiri. Begitu juga dari para pedagang menerima supplai barang yang diikuti dengan pembuatan nota untuk supplier yang digunakan sebagai bukti nanti ketika sudah jatuh tempo maka supplier memiliki hak untuk menagih pembayaran atas barang yang sudah diserahterimakan kepada pedagang Pasar Klewer.

\section{Kekuatan Mengikat Dari Asas Iktikad} Baik Dalam Perjanjian Lisan Antara Pedagang dan Penyuplai Barang di Pasar Klewer Surakarta Apabila Terjadi Wanprestasi

Berdasarkan hasil penelitian mengenai problematika yang timbul dalam pelaksanaan transaksi lisan antara pedagang dengan penyuplai barang di Pasar Klewer, maka diperoleh hasil sebagai berikut: transaksi lisan yang biasa terjadi di Pasar Klewer antara pedagang dengan penyuplai barang merupakan hal yang memenuhi asas kepatutan dan hukum kebiasaan atau local wisdom di lingkungan Pasar Klewer. Sehingga apabila terjadi permasalahan dalam pelaksanaan transaksi, juga diselesaikan dengan hukum kebiasaan yang ada di Pasar Klewer, yakni diselesaikan dengan jalan damai dengan melakukan titik temu komunikasi yang dilakukan baik antara pedagang dengan penyuplai barang. Namun sejauh mana perjanjian lisan ini dapat memiliki kekuatan mengikat bagi kedua belah pihak dalam hal terjadinya permasalahan tersebut. Adakalanya salah satu pihak tidak mau melaksanakan kewajiban yang telah disepakati dan pihak yang lain pun tidak dapat menuntut haknya sebab memang tidak ada perjanjian tertulis sebelumnya. Problematika yang timbul dari transaksi akan diselesaikan berdasarkan kebiasaan atau hukum adat yang berlaku di Pasar tersebut. Hal ini melahirkan sistem keyakinan yang berpengaruh dalam kebiasaan hingga cara bagaimana berkomunikasi. [Christeward, 2014:4].

Bahwa berdasarkan wawancara dengan pedagang lain yaitu Nina, juga melakukan kesepakatan dalam bentuk lisan dan dilakukan secara tunai. Dalam melakukan transaksi dengan penyuplai barang biasanya Nina membayar barang yang dititipkan langsung secara tunai sehingga tidak ada yang tidak dibayar secara langsung. Nina mengaku kesepakatan yang dibuat dengan penyuplai setelah penitipan barang di pagi hari dengan membayar di sore harinya, sehingga sistem yang dipakai adalah sistem harian. Hal ini sebagaimana yang dijelaskan sebagai berikut: "Ya kesepakatannya pokoknya pake nota biasa. Ada yang cash ada yang ndak. Kalo perjanjian tertulis atau 
kontrak resmi ya ndak ada. Ada juga yang mereka nyetok pagi terus tinggal bayar di sore harinya." Mengenai permasalahan dalam bertransaksi antara pedagang dengan penyuplai, Nina mengaku sering terjadi masalah-masalah kecil seperti nota yang dibuat tidak sesuai dengan yang dijanjikan atau diucapkan. Penyelesaiannya dengan jalan komunikasi biasa, sehingga nota tertulis yang dibuat walaupun bukan berupa perjanjian dan tidak mempunyai kekuatan hukum mengikat tetap bergantung dan kembali kepada masing-masing pihak yang menjalankan perjanjian, sebagaimana yang diungkapkan berikut: "Rata-rata penghasilan kotor di kios saya bisa mencapai 50 juta setiap bulan. Kalo jumlah rata-rata penyuplainya kisaran lebih dari 20 orang. Kalo masalah dengan supplier paling-paling notanya salah atau barangnya nggak sesuai, ya tinggal disesuaikan. Ya intinya saling percaya saja. Hanya saja kelemahannya misal dititipkan dulu ya otomatis ngutang, bayarnya lama, tapi barangnya lebih cepet."

Terkait dengan pembuktian hukum akan adanya perjanjian lisan, maka penyelesaian litigasi pun sulit sebab setiap dalil yang dikemukakan harus dibuktikan. Permasalahan ini sering terjadi dalam perjanjian lisan, dimana salah satu pihak melakukan wanprestasi dan berdalih bahwa tidak pernah ada perjanjian. Oleh sebab itu, harus dilakukan konstruksi bukti hukum agar perbuatan hukum tersebut mendapat dasar penyelesaian yang jelas. Misalnya, pinjam meminjam uang dari tangan ke tangan tanpa bukti kuitansi dan tanpa saksi, sedangkan perbuatan tersebut oleh para pihak sama-sama diakui dilakukan. Di dalam rumusan Pasal 1865 KUHPerdata menyebutkan bahwa, "barang siapa mendalilkan sesuatu hak harus membuktikannya." Selanjutnya dalam rumusan Pasal 1866 KUHPerdata disebutkan, "alat bukti yang dapat dipakai untuk membuktikan suatu dalil terdiri atas: bukti tulisan, bukti saksi, persangkaan, pengakuan, dan sumpah. Berdasarkan hasil wawancara dengan beberapa pedagang di Pasar Klewer, dapat ditemukan bahwa, problematika yang sering terjadi dalam penerapan transaksi lisan antara pedagang Pasar Klewer dengan penyuplai barang adalah di antaranya, pertama tentang nota yang dibuat tidak sesuai yang dijanjikan dalam transaksi atau nota yang keliru dalam pencatatan. Sering kali terjadi pencacatan yang berbeda antara pedagang dengan penyuplai barang, namun penyelesaian hal tersebut adalah dengan komunikasi dan mengulang pencatatan transaksi tersebut. Sehingga wanprestasi yang timbul diselesaikan dengan mengedepankan asas iktikad baik yang dilakukan dengan cara damai.

Problematika lainnya yang sering terjadi adalah apabila barang yang dititipkan rusak atau cacat, maka sesuai kesepakatan antara pedagang dan penyuplai barang, dapat ditukar dengan barang dagangan lain yang tidak cacat. Sehingga proses bertransaksi secara lisan tetap dengan memegang teguh asas iktikad baik dan asas saling percaya sehingga menumbuhkan iklim berdagang yang sehat meskipun dilakukan tanpa bukti atau tanpa nota tertulis. Berdasarkan hasil wawancara penulis dengan beberapa pedagang di Pasar Klewer, mereka tetap akan menerapkan kesepakatan dalam bentuk lisan tersebut ke depannya dan tidak akan berubah. Sebab jika harus menggunakan perjanjian tertulis, malah akan menyalahi kebiasaan yang sudah terjadi sejak cukup lama antara pedagang dan penyuplai barang di Pasar Klewer, dan malah akan lebih kaku dalam penyelesaian kewajiban masing-masih pihak satu dengan 
yang lain. Keuntungan dari kesepakatan lisan adalah lebih sederhana serta tidak membutuhkan klausul-klausul yang perlu ditungkan dalam perjanjian tertulis, dan tetap mengikat satu sama lain antara pedagang dan penyuplai barang dengan tetap menjaga asas itikad baik maupun asas saling percaya merupakan hal yang sudah disepakati dan diterima bersama di lingkungan masyarakat Pasar Klewer sehingga akan lebih fleksibel, serta memudahkan pedagang Pasar Klewer dalam menjual barang-barang dagangannya dan mencukupi kebutuhannya.

Menurut Subekti, dalam Hukum Perjanjian, menyatakan terdapat empat macam wanprestasi, yaitu: tidak melakukan apa yang disanggupi akan dilakukan; melaksanakan tetapi tidak sebagaimana dijanjikannya; melakukan apa yang dijanjikannya tetapi terlambat; dan melakukan sesuatu yang menurut perjanjian tidak boleh dilakukan.

\section{SIMPULAN}

Bahwa perjanjian tidak tertulis yang dilakukan oleh Pedagang dengan Penyuplai barang di Pasar Klewer tetap sah dan mengikat kedua belah pihak, akan tetapi lemah dalam hal pembuktian apabila terjadi sengketa perdata. Di satu sisi lainnya kita mencoba meninjau dari penerapan asas iktikad baik dalam perjanjian lisan antara pedagang dengan penyuplai barang berdasarkan local wisdom yang diwujudkan dalam bentuk kesepakatan lisan dengan dasar nota tertulis. Untuk pemenuhan asas iktikad baik terpenuhi sebagaimana ketentuan Pasal 1338 ayat (3) KUHPerdata yang berbunyi: "Perjanjian harus dilaksanakan dengan iktikad baik." Akan tetapi bukti berupa nota tertulis sangat lemah apabila dijadikan alat bukti jika terjadi wanprestasi atau permasalahan perdata lainnya.

Dalam kesepakatan lisan yang dibuat oleh pedagang Pasar Klewer memuat tata cara, aturan, dan prinsip-prinsip moral yang secara umum sudah menjadi kebiasaan berdagang atau bertransaksi di Pasar Klewer. Jadi selain asas iktikad baik di dalam pelaksanaan perjanjian lisan tersebut, juga muncul asas lain yaitu asas kebiasaan. Asas ini diatur dalam pasal 1339 jo. Pasal 1347 KUH Perdata, yang dipandang sebagai bagian dari perjanjian tidak hanya mengikat untuk apa saja yang secara tegas diatur, akan tetapi juga hal-hal yang dalam kebiasaan dan lazim diikuti.

\section{DAFTAR PUSTAKA}

Alus, Christeward. (2014). Journal Acta Diurna: Peran Lembaga Adat dalam Pelestarian Kearifan Lokal Suku Sahu di Desa Balisoan Kecamatan Sahu Kabupaten Halmahera Barat, Volume III, No. 4.

Budiono, Herlien. (2015). Asas Keseimbangan bagi Hukum Perjanjian Indonesia. Bandung: Penerbit PT Citra Aditya Bakti.

Dewi, Gemala dkk. (2006). Hukum Perikatan Islam di Indonesia, Cetakan ke-2, Jakarta: Kencana Prenada Media Group.

Dicko, Billy Stepanus Harefa dan Tuhana. (2016). Kekuatan Perjanjian Lisan Apabila Terjadi Wanprestasi (Studi Putusan Pengadilan Negeri Yogyakarta Nomor 44/PDT.G/2015/PN.YYK). Privat Law Vo. IV No.2. 
Fajarini, U. (2014). Peranan Kearifan Lokal dalam Pendidikan Karakter. Sosio Didaktika 1 (2): 123- 130.

Hapsari, Dwi Ratna Indri. (2014). Jurnal Repertorium: Kontrak dalam Kitab UndangUndang Hukum Perdata dan Hukum Islam (Suatu Kajian dalam Perspektif AsasAsas Hukum. ISSN: 2355-2646, 1 Januari-Juni, 2014.

Herniwati. (2015). Jurnal Ipteks Terapan (Research of Applied Science and Education): Penerapan Pasal 1320 KUHPerdata terhadap Jual Beli secara Online (ECommerce), V8.i4.

Khairandy, Ridwan. (2004). Iktikad Baik dalam Kebebasan Berkontrak. Jakarta: Program Pascasarjana Fakultas Hukum Universitas Indonesia.

Maeijer, J.J.M., sebagaimana dikutip dari Herlien Budiono. (2006). Asas Keseimbangan bagi Hukum Perjanjian Indonesia: Hukum Perjanjian Berlandaskan Asas-Asas Wigati Indonesia. Bandung: PT. Citra Aditya Bakti.

Moleong, Lexy J. Metodologi Penelitian Kualitatif. Bandung: Remaja Rosdakarya Offset.

Simamora, Novalia Arnita. (2015). USU Law Journal: Asas Iktikad Baik dalam Perjanjian Pendahuluan (Voor Overeenkomst) Pada Perjanjian Pengikatan Jual Beli Rumah (Studi Putusan Pengadilan Negeri Simalungun No 37/Pdt/Plw/2012/SIM), Vol.3, No.3. November, 2015.

Sri Lestari, Pedagang Pasar Klewer. Wawancara Pribadi, Sidoarjo, 19 Maret 2018, pukul 10:30 WIB.

Subekti, R. (1996). Hukum Perjanjian. Jakarta: Intermasa.

Syaifuddin, Muhammad. (2012). Hukum Kontrak: Memahami Kontrak dalam Perspektif Filsafat, Teori, Dogmatik, dan Praktik Hukum (Seri Pengayaan Hukum Perikatan). Bandung: Penerbit Mandar Maju.

Tri, Pedagang Pasar Klewer. Wawancara Pribadi, Surakarta, 10 September 2019, pukul 10:30 WIB.

Wignjosoebroto, Soetandyo. Silabus Metode Penelitian Hukum. Surabaya: Program Pascasarjana Universitas Airlangga.

Winda, Pedagang Pasar Klewer. Wawancara Pribadi, Surakarta, 10 September 2019, pukul 10:30 WIB.

Wiwis, Pedagang Pasar Klewer. Wawancara Pribadi, Surakarta, 10 September 2019, pukul 10:30 WIB.

Yulianti, Rahmani Timorita. (2008). Asas-Asas Perjanjian (Akad) dalam Hukum Kontrak Syari'ah, " La Riba Jurnal Ekonomi Islam. Vol. II, No. 1, Juli, 2008.

https://www.wikipedia.com. Sejarah Pasar Klewer. diakses 20 Maret 2018, pukul 15:00.

https://jdih.surakarta.go.id. 